\title{
THE CONCEPTION OF CULTURAL SPACE REVITALIZATION AS A WAY TO INCREASE DOWNTOWN ATTRACTIVENESS. A CASE STUDY OF CHOSEN MEDIUM-SIZED TOWNS IN THE WIELKOPOLSKA REGION
}

\author{
DOMINIKA PAZDER \\ Poznań University of Technology, Institute of Architecture and Spatial Planning; Adam Mickiewicz University, \\ Institute of Socio-Economic Geography and Spatial Management, Poznań, Poland
}

Manuscript received July 1, 2011

Revised version October 28, 2011

PAZDer D., The conception of cultural space revitalization as a way to increase downtown attractiveness. A case study of chosen medium-sized towns in the Wielkopolska region. Quaestiones Geographicae 30(4), Bogucki Wydawnictwo Naukowe, Poznań 2011, pp. 63-67. DOI 10.2478/v10117-011-0039-4, ISBN 978-83-62662-88-3, ISSN 0137-477X.

AвstRact. This paper deals with chosen aspects of revitalization within the downtown area of Polish mediumsized towns. The author underlines the necessity of introducing a mixed-use offer in the city centre. Not only commerce and services, but also cultural functions and values should be promoted in the contemporary city centre. Therefore the idea is presented of turning the downtown public space into a single, homogeneous and integrated spatial-functional system. The system is to introduce cultural functions on the basis of so-called cultural space, which is defined here as a specific kind of public space of historical or cultural value, or that has the potential to develop this kind of new functions.

KEY WORDS: downtown area, revitalization, revival, cultural functions, values, integrated system

Dominika Pazder, Institute of Socio-Economic Geography and Spatial Management, Adam Mickiewicz University, ul. Dzięgielowa 27, 61-680 Poznań, Poland; e-mail:pazder@amu.edu.pl

\section{Identification of the research problem}

Modern political, economic and social conditions pose new challenges for Polish mediumsized towns. They stem, inter alia, from Poland's accession to the European Union as well as from general dynamic changes of civilization. Many medium-sized towns in Poland lost their position in the late 1990s because of changes in the country's administrative division into provinces. The phenomena of globalization, consumerism, the unification of attitudes and social assessments also require a new approach to the cultural heritage. In order to preserve cultural values for future generations while adapting the city centre to a new reality, it is necessary to revise the approach to the issue of revitalization. In addition, traditionally understood protection and active protection associated with the concept of heritage planning and management (Ashworth 1997, Couch 1990) take an important place in the process of urban change. While West European states have 
already dealt with downtown revitalization, in our post-communist country those problems still wait to be solved in medium-sized towns.

Those activities gain special significance in terms of cultural regeneration within the downtown area. This is the so-called cultural space (Ciołek 1964, Kołodziejski 1989) understood as sites rich in cultural heritage, characterized by the appearance of historic buildings and contemporary cultural values. Cultural space is a special kind of public space, consisting of squares, streets and parks. This kind of space has always been the basic material of inner-city areas and the domain of more intensive interactions and social contacts.

It should be noted that in the modern era of changes, cultural phenomena have been significantly re-evaluated - our lives and the world around us is divided into physical and virtual. There is a danger that the intangible reality created by advertising, computerization and the Internet will have a greater impact on the value of items than their actual worth. With an effective campaign, one can even sell a poor-quality item, but in an attractive package that catches the eye. To paraphrase, the quality of downtown space is in its authenticity and the already existing cultural values. They should gain primary importance in the process of renewal, becoming the basis for developing a new quality which highlights the existing values and character of the place.

The development of urban space should be balanced, which means that it should meet the needs of today without compromising the ability to satisfy those of future generations. The aim is to achieve a balance between the various factors provoking changes in urban space and to provide sustainable development. Fulfilling those objectives is only possible with the introduction of appropriate mechanisms to regulate changes (Gzell 2001).

The implementation of the principles of sustainable development is intended to improve the built environment within downtown space. This can be achieved by strengthening the natural system, protection and revitalization of cultural heritage values and traditions, use of urban reserves to activate and use the existing potential, as well as harmonious development of the built environment by creating an integrated system of public spaces (streets and transport, together with the surrounding buildings of multifunctional nature outside the city, well-connected with downtown areas).

Urban regeneration should be synonymous with the creation of new attractive and activating functions within the city. Particular attention should be paid to the revitalization of the historic fabric and an integrated policy of city development taking into account spatial values as well as social and economic aspects (Ziobrowski 2007). Development of tourism is also important because it helps to increase the interest in culture, local identity, and traditional arts and crafts. This strengthens a community's awareness of the importance and value of its own culture, and hence of the need to preserve and sustain it.

The relationship between the cultural landscape and the socio-economic system can be seen particularly clearly in the period of transition which took place in Poland after 1989. The operation of the city changed then, so new legal instruments are needed to control the fast-growing free market, especially in the most valuable city areas. It is necessary to incorporate the cultural heritage in the new economic system, which means finding a compromise between the demands of protection and the requirements of the economy. Those measures are particularly important because virtually Polish cities are still in the process of transformation. Therefore, synonymous with the contemporary sense of protection should be a change in city management (Purchla 1993, 2005). Comprehensive protection of cultural values of the downtown area is linked to the economic dimension of culture. In today's consumerist society, culture is no longer seen as an unproductive sector. Culture is part of a coherent system of economic and social life. Accordingly, there is no effective protection of city centres without effective strategies in economics, management and social policy. Modern heritage is not only the physical preservation of the urban stock, but its interpretation, marketing and operation. Such reasoning underlies active protection that forces an interdisciplinary approach to the historical city, because heritage is not only a spiritual matter, but also physical objects subject to the laws of economics (Purchla 2005). 
For this reason, it is important to introduce new functions into degraded city space. A guarantee of efficiency and conservation is the creation of a proper image of the city (Lynch 1969), whose attractiveness is linked directly with the existing cultural potential and the heritage preserved. This means eliminating functions inappropriate for the downtown area and highlighting the dominance of what should be characteristic features within it: public and commercial services as well as various culture-related functions (theatres, cinemas, concert halls, museums, galleries, educational centres, information and cultural centres). It is the right way to ensure downtown zones high quality as well as social and spatial attractiveness.

Arranging the existing urban structure of the downtown area with the use of nodal points of the cultural function means crystallizing the downtown area in terms of spatial composition. This is also to ensure its proper development based on the use of the existing values. This approach can also enhance the economic attractiveness of those zones, to a degree depending on the scale and character of the city.

\section{Aim and scope of the research}

The main aim of this work is to create a planning tool serving to integrate spatial and social aspects of downtown revitalization with the area's existing or potential cultural values and functions. Such an instrument consists of two elements: an Integrated System of Cultural Space, and a Cultural Investment Offer. The Integrated System of Cultural Space is used to direct investment in the downtown area, while the Cultural Investment Offer is designed to complement it in greater detail. This tool is intended to aid urban planning and programming processes at the level between a Study of Conditions and Directions of Spatial Development and a local spatial development plan.

The tool aims to contribute to the programming of the revitalization process in accordance with the principles of sustainable development, and not just in terms of benefits of a free-market economy. It is intended to increase the competitiveness of the downtown zone by boosting the attractiveness of its cultural space system as well as to introduce complementary functions (merchants) that positively affect the quality, image and visual reception of this zone. The tool can also be useful for local authorities and potential investors, since it specifies that the transformation and new features are possible to implement within the Integrated System of Cultural Space. The proposed planning tool is to support the development of cultural features in the downtown area based on existing resources. It is intended to operate at three levels: spatial, social and economic. This helps to ensure the correctness of the revitalization process in the downtown area.

\section{Research method}

The author chose as case study examples the downtown areas of medium-sized towns in the Wielkopolska region: Leszno, Konin and Kalisz. The research is limited to spatial issues, which results from the author's line of professional interest. The invented research method is based on an analysis at three levels, or stages:

1) Level 1: Identification of the existing functional and spatial situation of the downtown areas of the medium-sized towns in question. First of all, the given downtown area is demarcated as a result of an analysis of: - the existing communication system, $\bullet$ the existing cultural values and cultural functions, and $\bullet$ the existing density of buildings. The next step is to identify cultural space in the downtown area in terms of: - its historic value and cultural heritage, $\bullet$ contemporary architectural value, - cultural function, and - the potential to introduce cultural functions.

2) Level 2: Mapping out the Integrated System of Cultural Space within the demarcated downtown area. The first step is to assess individual elements within the integrated system of cultural space and to define future renewal directions concerning active protection of the existing cultural values, activating the existing cultural functions as well as introducing new ones. The next steps are: $\bullet$ an assessment of the attractiveness of individual cultural space elements within the system, • mapping out concentration zones of the cultural space, 
- evaluation of those concentration zones, and

- identification of the focal points rank. The result of this part of the research is a demarcation of the Integrated System of Cultural Space based on the dependency and hierarchy of the focal points and links. It was done to identify stages in the revitalization process and to point out the most important and urgent cultural spaces to be healed within the downtown area.

3) Level 3: Cultural Investment Offer (CIO) defined for the given focal points of cultural space as a result of the research at the two previous levels. This level is to specify precisely the existing spatial situation with reference to: - the urban composition (urban interiors and links) as well as - aspects of perception (landmarks, pieces of small architecture, aesthetics). The main aim of this part is to draw the right conclusions helping to direct the spatial reshaping process concerning the introduction of - new architecture and $\bullet$ new functions. This is to control at a larger scale the alterations possible to make within the given cultural space. The Cultural Investment Offer is also to underline how important the individual character and unique values of the given cultural space are in the spatial and social revitalization process.

The presented method of three-level analysis is to design and create a coherent system linking downtown cultural spaces of various importance. The research was conducted in such a way that at each successive level it was based on the results of studies carried out at an earlier stage. The division of the research into the three levels rests on the rule for testing - from the general to the specific: first, the whole downtown area, then the public spaces in it, and then the nodal cultural spaces set in them.

The research showed similarities and differences in the analysed case studies of the Wielkopolska towns of Leszno, Kalisz and Konin. All three meet the necessary conditions for the application of the proposed planning tool: in each it is possible to demarcate a downtown area, there are cultural values and functions as well as a potential to develop new cultural features, and each has to improve the quality and attractiveness of its downtown area. In all of them it is possible to designate an Integrated Cultural Area consisting of core areas and linkages between them. Characteristic of each is the existence of urban core areas of the highest, a high and a medium rank. The determinant of the parent node is the main town square of historic significance. In addition, within the urban historic core in all three examples there are nodes of the largest concentration of cultural space. The chief differences are in the quantity and location of focal points of the Integrated System of Cultural Space.

\section{Application of the planning tool}

The presented planning tool helps to identify areas within the downtown zone where restoration should be given the right direction through the introduction of cultural functions and the use of the existing spatial potential. Determining the Integrated System of Cultural Space and indicating areas for which the Cultural Investment Offer must be specified is to show that the transformation of the downtown fabric may not occur spontaneously, without a long-term plan and coordinated interdisciplinary activities. The downtown area should be considered as a whole in order to achieve a harmonious coexistence of the heritage and the new spatial structures. The concept of spatial and social crystallization leads to actions taken in the spatial aspect of renewal being combined with social ones while taking into account the important economic factor. This kind of integrated, holistic approach to questions of revitalization helps to increase the attractiveness of the downtown area, and not only to protect, but also to adapt cultural values to the fast-changing contemporary lifestyle.

The planning tool for downtown revitalization presented in the paper can be used for each medium-sized Polish town. However, the following conditions are required: • one can demarcate a downtown area in its structure, $\bullet$ there are cultural values in it, $\bullet$ it has a potential for developing new cultural functions, and $\bullet$ there is a need to improve the quality and attractiveness of the downtown zone. Although the research was limited to the three selected examples of a medium-sized town, the research method applied is universal. The inclusion of issues relevant to the 
transformation and development of downtown areas at three levels: spatial, social and economic, allows its use in other fields of science.

The Integrated System of Cultural Space and the Cultural Investment Offer provide guidance for proper ways of active protection or activation of the existing cultural values and the introduction of new cultural functions to the downtown area. The content and way of presentation of the Cultural Investment Offer can vary depending on interdisciplinary needs. The Offer is formulated as a result of detailed analyses of the existing spatial, social and economic situation. The presented planning tool can also be used in the decision process concerning investment phasing in downtown revitalization at the local government level in addition to master plans.

\section{References}

Ashworth G.J., 1997. Planowanie dziedzictwa (Heritage planning). In: Broński K., Purchla J. \& Zuziak Z.K. (eds), Miasto historyczne. Potencjat dziedzictwa. Międzynarodowe Centrum Kultury, Kraków: 25-48.

Blowers A., 1993. Planning for a sustainable environment. A report by the Town and Country Planning Association. Earthscan, London.

Bonenberg W., 2007. Miejska przestrzeń kreatywna (Creative urban space). Zeszyty Naukowe Politechniki Poznańskiej, 10. Wydawnictwo Politechniki Poznańskiej, Poznań.

Castex J., Pannerai P., Depaule J.C. \& Samuels I., 2004. Urban forms. The death and life of the urban block. Architectural Press, Oxford, Boston.

Cichy-Pazder E., 1998. Humanistyczne podstawy kompozycji miast. Wybrane aspekty percepcyjne i behawioralne (Humanistic foundations of the composition of cities. Selected perceptual and behavioural aspects). Ośrodek Kształcenia Urbanistów Politechnika Krakowska, Kraków.

Cichy-Pazder E., 2005. Zrównoważona przestrzeń śródmiejska. Przestrzeń publiczna współczesnego miasta (A balanced downtown space. The public space of the modern city). Architektura. Czasopismo Techniczne, 1. Wydawnictwo Politechniki Krakowskiej.

Ciołek G., 1964. Zarys ochrony i kształtowania krajobrazu (An outline of landscape planning and protection). Wydawnictwo Arkady, Warszawa.

Couch C., 1990. Urban renewal. Theory and practice. Macmillan Education, London.

Gehl J. \& Gemzøe L., 2003. New city spaces. Danish Architectural Press, Copenhagen.

Groep Planning, 1996. Tisser l'espace 1966-1996. Editeur Brugeois Mark van de Wiele, Brugges.

Gzell S., 2001. Projektowanie urbanistyczne jako jedno z narzędzi równoważenia rozwoju miast - przykład placów Warszawy i Berlina (Urban design as a tool for balancing urban development - an example of Warsaw and Berlin squares). In: Heczko-Hyłowa E. (ed.), Trwały rozwój polskich miast nowym wyzwaniem dla planowania $i$ zarzadzania przestrzenia. Wydawnictwo Politechniki Krakowskiej, Kraków.

Kołodziejski J., 1989. Wprowadzenie (An introduction). In: Parteka T. (ed.), Przestrzeń kulturowa w planowaniu przestrzennym. PAN, Warszawa.

Lynch K., 1969. L'image de la cite. Dunod, Paris.

Purchla J., 1993. European Cultural Month in Cracow - June 1992. Międzynarodowe Centrum Kultury, Kraków.

Purchla J., 2005. Dziedzictwo a transformacja (Heritage and the transformation). Międzynarodowe Centrum Kultury, Kraków.

Rapoport A., 1977. Human aspects of urban form. Towards a man-environment approach to urban form and design. Pergamon Press, New York.

Trieb M., 1970. Simulation de l'espace urbain. AIPA, Paris.

Ziobrowski Z., 2007. Gospodarowanie przestrzenią w Polsce w świetle spójności z Unią Europejską - uwarunkowania, kierunki zmian (Space management in Poland in the light of cohesion with the European Union - determinants and directions of change). Problemy rozwoju miast. Instytut Rozwoju Miast, Kraków. 